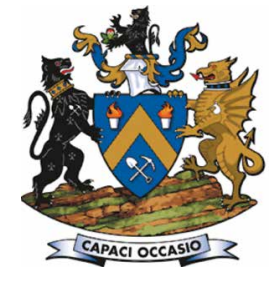

Affiliation:

1 University of the Witwatersrand, Johannesburg, South Africa.

Correspondence to:

R. Sefako

Email:

1420412@students.wits.ac.za

Dates:

Received: 25 Oct. 2018

Revised: 27 Jun. 2019

Accepted: 30 Jul. 2019

Published: November 2019

How to cite:

Sefako, R., Sibanda, V., and

Sekgarametso

PGM extraction from oxidized

ores using flotation and leaching.

The Southern African Insitute of

Mining and Metallurgy

DOI ID:

http://dx.doi.org/10.17159/2411$9717 / 287 / 2019$

\title{
PGM extraction from oxidized ores using flotation and leaching
}

\author{
R. Sefako ${ }^{1}$, V. Sibanda ${ }^{1}$, and K. Sekgarametso ${ }^{1}$
}

\begin{abstract}
Synopsis
Flotation and leaching were investigated as possible processing routes for improving PGM recovery from a Southern African oxidized PGM ore. Different flotation reagent schemes and lixiviants were evaluated and their PGMs extraction response measured. Characterization of the PGM ore used in this study indicated that it was enriched in oxide minerals as a result of weathering and therefore oxidic. The maximum PGM flotation recovery achieved using sulphide co-collector schemes was $55.1 \% 3 \mathrm{E}$ (Pt, $\mathrm{Pd}$, and $\mathrm{Au}$ ). Application of the hydroxamate oxide collector improved the flotation recovery to $74.7 \%$ 3E. The superior PGM recoveries achieved with hydroxamates probably lies in their ability to form complexes with base metals such as iron. Direct leaching of oxidic PGM ore using different acids yielded relatively low PGM extractions. Leaching in hydrochloric acid achieved extractions of $36.6 \% \mathrm{Pt}$ and $8.8 \%$ $\mathrm{Pd}$, nitric acid achieved extractions of $34.5 \% \mathrm{Pt}$ and $7.1 \% \mathrm{Pd}$. The best leaching results were obtained using aqua regia, with extractions of $48 \% \mathrm{Pt}$ and $24.5 \% \mathrm{Pd}$. In view of the low PGM extractions obtained by leaching ROM ore, it was considered more promising to leach the concentrate as a way of further upgrading it. The flotation concentrate with the highest PGM recovery was leached using sulphuric acid in order to remove the base metals and further enrich it in PGMs. Extractions of $73.3 \% \mathrm{Cu}, 82.9 \% \mathrm{Ni}$, and $8.1 \%$ Fe were achieved.
\end{abstract}

\section{Keywords}

PGM extraction, oxidized ore, flotation, leaching.

\section{Introduction}

Southern Africa, specifically South Africa and Zimbabwe, hosts the worlds' largest deposits of platinum group metals in the Bushveld Complex (BC), South Africa and in the Main Sulphide Zone (MSZ) of the Great Dyke in Zimbabwe. The sulphide-rich BIC and MSZ are mostly exploited by underground mines and the ore is treated by conventional metallurgical processes such as crushing, grinding, flotation, smelting and matte production, and chemical refining. However, the fast depletion of sulphide PGMbearing minerals has triggered interest in exploring the possibilities of recovery of the PGMs from nearsurface oxidized PGM ores, which have proven to be more difficult to process by conventional means, as an alternative source to sustain production of PGMs (Evans, 2002; Cramer, 2001). The resources of oxidized PGM ores that are unmined, mined and stockpiled, or discarded as overburden waste in South Africa and Zimbabwe are estimated at over $500 \mathrm{Mt}$. The economic benefits that could be realized in the event of an alternative and effective processing technique being developed would be immense (Sefako, Sekgarametso, and Sibanda, 2017).

Earlier attempts by PGM concentrator plants in South Africa and Zimbabwe to process oxidized PGM ores by conventional flotation methods yielded poor recoveries, hindering commercial exploitation of these resources (Oberthür et al., 2013). This has been attributed to some PGM values that fall within the floatable size range not being floated and subsequently reporting to the tailings (Ramonotsi, 2011). Studies attribute the poor PGM flotation recoveries to the complex mineralogy of oxidized PGM ores as a result of alteration of the original pristine sulphide ores by weathering and oxidation. The weathering of the PGM-bearing base metal sulphides such as pentlandite $\left[(\mathrm{Fe}, \mathrm{Ni})_{9} \mathrm{~S}_{8}\right]$, pyrrhotite $\left(\mathrm{Fe}_{1-\mathrm{x}} \mathrm{S}\right)$, and chalcopyrite (CuFeS2) is thought to proceed by diffusion of iron from the bulk lattice to the surface, where it is oxidized. The oxidation product is hydrophilic iron (III) oxyhydroxide ( $\mathrm{FeOOH})$, which coats the base metal particle surfaces and renders them less responsive to sulphide flotation collectors (Legrand, Bancroft, and Nesbitt, 2005; Buckley and Woods, 1984; Vaughan, Becker, and Wright, 1997; Mielczarski et al., 1996). The oxidation of Pt and Pd bismuth telluride minerals also results in the formation of hydrophobic layers of Bi (III) and Te (IV) oxides and/hydroxides on particle surfaces (Elvy, 


\section{PGM extraction from oxidized ores using flotation and leaching}

\begin{tabular}{|c|c|c|c|c|c|c|c|}
\hline \multicolumn{8}{|c|}{$\begin{array}{l}\text { Comparison of mineralogical characterization for pristine and weathered PGM } \\
\text { ores from the MSZ, Great Dyke (adapted from (Oberthür et al., 2013) }\end{array}$} \\
\hline \multirow[b]{2}{*}{ Ore type } & \multirow{2}{*}{$\begin{array}{l}\text { Discrete } \\
\text { PGM } \\
\text { grains (n) }\end{array}$} & \multicolumn{6}{|c|}{ PGM minerals identified (\%) } \\
\hline & & $\begin{array}{l}(\mathrm{Pt}, \mathrm{Pd}) \\
(\mathrm{Bi}, \mathrm{Te})^{*}\end{array}$ & $\mathrm{PtAs}_{2}$ & (Pt,Pd,Ni)S & $\begin{array}{l}\text { Pt and Pt- } \\
\text { Fe alloys }\end{array}$ & $\begin{array}{l}\text { PGE-sulph- } \\
\text { arsenides }\end{array}$ & Others \\
\hline $\begin{array}{l}\text { Pristine MSZ } \\
\text { sulphide }\end{array}$ & 801 & 50.1 & 19.0 & 8.5 & 2.4 & 11.9 & 8.7 \\
\hline $\begin{array}{l}\text { Oxidized MSZ } \\
\text { sulphide }\end{array}$ & 1293 & 11.4 & 57.2 & 28.3 & 3.1 & 0 & 0 \\
\hline
\end{tabular}

Williams, and Buckley, 1996). Shackleton (2007) suggested that the oxidation of PGE bismuth telluride minerals could most probably be attributed to the formation of bismuth oxides because the oxidation potentials of bismuth are superior to those of tellurides. A comparison of pristine PGM ore and weathered PGM ore from the MSZ is shown in Table I.

Table I shows that the oxidized PGM ore contained much more sperrylite $\left(\mathrm{PtAs}_{2}\right)$ and cooperite combined with palladium and nickel sulphides with the general formula ((Pt,Pd,Ni)S) and significantly lower (Pt,Pd)-bismuthotellurides compared to the pristine ore sample, which indicates its altered nature. Additionally, the platinum group elements (PGEs) in oxidized PGM ores also exhibit poor association with base metal minerals which are easily recoverable with conventional sulphide xanthate collectors (Becker. Wiese, and Ramonotsi, 2014). This complex mineralogical characterization data was used as the basis for devising non-conventional reagent suites to improve PGM recoveries from oxidized ore.

Recently, several researchers have investigated different methods to improve flotation recoveries of PGEs from the oxidized PGM ores, including ore pretreatment with mineral acids before flotation and sulphidization followed by xanthate flotation. Pretreatment with sulphuric acid marginally improved recoveries, possibly by removing the oxide layer from the mineral surfaces so that fresh surfaces would be accessible to the collectors (Ramonotsi, 2011). However, the implementation of a corrosive acid preleaching process would require undesirable infrastructural changes such as rubber lining of tanks or use of stainless steel tanks, leading to high capital and operating costs. The alternative would be to add equipment for neutralization of the slurry to $\mathrm{pH} 9$ prior to flotation. Newell and Bradshaw (2007) improved PGM flotation recoveries from oxidized ore by using controlled potential sulphidization to restore the floatability of oxidized pentlandite. Sulphidization is an aqueous process by which a non-sulphide mineral surface is converted to a sulphidelike surface and has been successfully used to improve the flotation recoveries of oxidized copper minerals and oxidized lead ores. (Orwe, Grano, and Lauder, 1998; Kongolo et al., 2003; Castro, Goldfarb, and Laskowski, 1974).

Studies by Lee et al. (2009) have indicated that hydroxamate co-collectors have the potential to improve PGM flotation recoveries from oxidized ores because they can selectively form complexes with some metals (Assis, Montenegro, and Peres, 1996). A further benefit of hydroxamates co-collectors is their ability to improve the PGM flotation recoveries from oxidized ores without reducing the performance of the traditional copper sulphide collectors. (Becker, Wiese, and Ramonotsi
(2014) indicated that it was possible to improve the PGM flotation recoveries from oxidized PGM ore by using the AM28 hydroxamate co-collector. However, poor concentrate PGM grades were achieved because the frothing properties of AM28 resulted in poor selectivity due to increased froth stability.

Some researchers have evaluated various hydrometallurgical processes as alternative routes to improve PGM extractions from oxide ores. The cyanidation process, which has proven to be effective for extraction of gold and silver by direct leaching of oxidized ores and concentrates, achieved low recoveries when applied to oxidized PGM ore (Musonda, 2015). Cyanidation of low-grade PGM flotation concentrates was also considered as a potential route for recovery of PGMs from low-grade ores (Mwase, Petersen, and Eksteen, 2012), but such ores require preleaching of base metals ( $\mathrm{Cu}$ and $\mathrm{Ni}$ ) to avoid high lixiviant consumption. However, the limited base metal recoveries by the alkaline hydrometallurgical techniques investigated so far and the refractoriness of platinum minerals such as sperrylite $\left(\mathrm{PtAs}_{2}\right)$ have hampered the development of commercial cyanide processes for the recovery of PGMs from low-grade and oxidized ores (Mwase, Petersen, and Eksteen, 2012; Shaik and Petersen, 2017; Mwase and Petersen, 2017). The other alternative maybe be the preleaching of base metals with sulphuric acid to upgrade the low-grade concentrates. This was considered in the current study.

The objectives of this investigation were first to conduct flotation test work on an oxidized PGM ore from the Mimosa mine in Zimbabwe using a sulphide flotation scheme and an oxide flotation scheme using alkyl hydroxamate (AM810), an improved hydroxamate co-collector which has not been tested previously on oxidized PGM ores, and then do a direct comparison of these schemes. Secondly, the direct leaching of the oxidized $\mathrm{PGM}$ ore using aqua regia, $\mathrm{HNO}_{3}, \mathrm{H}_{2} \mathrm{SO}_{4}$, and $\mathrm{HCL}$ was also evaluated for PGM extraction. The concentrate from the flotation test work with the highest recovery was then upgraded by leaching out base metals using sulphuric acid.

\section{Experimental methods}

\section{Sample preparation and characterization}

The ore was prepared for metallurgical test work by crushing to $100 \%-1 \mathrm{~mm}$, homogenizing, and rotary splitting to obtain $1 \mathrm{~kg}$ representative aliquots. Approximately $300 \mathrm{~g}$ representative samples of the oxidized ROM PGM ore were split out from the bulk and pulverized to finer than approximately $90 \%-75 \mu \mathrm{m}$ in preparation for head analyses. PGM head analyses (in duplicate) were done by fire assaying and lead collection with an ICP-OES finish. X-ray diffraction (XRD) analysis was also carried out 


\section{PGM extraction from oxidized ores using flotation and leaching}

\begin{tabular}{|c|c|c|c|c|}
\hline \multicolumn{5}{|c|}{$\begin{array}{l}\text { Table II } \\
\text { Summary of flotation reagent conditions tested }\end{array}$} \\
\hline $\begin{array}{c}\text { Sequence of } \\
\text { reagent dosages }\end{array}$ & Reagent & Function & $\begin{array}{l}\text { Typical reagent } \\
\text { dosages (g/t) }\end{array}$ & $\begin{array}{l}\text { Conditioning } \\
\text { time (min) }\end{array}$ \\
\hline 1 & Copper sulphate & Activator & $40-50$ & 5 \\
\hline 2 & $\begin{array}{l}\text { Sodium isobutyl xanthate } \\
\text { (SIBX) }\end{array}$ & $\begin{array}{l}\text { Primary } \\
\text { collector }\end{array}$ & $100-150$ & 2 \\
\hline \multirow{3}{*}{3} & $\begin{array}{l}\text { FLOMIN C7133 (xanthogen } \\
+ \text { IPETC blend) }\end{array}$ & $\begin{array}{l}\text { Secondary } \\
\text { collector }\end{array}$ & $30-50$ & 2 \\
\hline & $\begin{array}{l}\text { FLOMIN C5460 (sodium } \\
\text { isobutyl dithiophosphate + } \\
\text { IPETC blend) }\end{array}$ & $\begin{array}{l}\text { Secondary } \\
\text { collector }\end{array}$ & $30-50$ & 2 \\
\hline & $\begin{array}{l}\text { AM } 810 \text { (hydroxamate } \\
\text { collector) }\end{array}$ & $\begin{array}{l}\text { Oxide co- } \\
\text { collector }\end{array}$ & $50-100$ & 2 \\
\hline 4 & Depressant M98B & Depressant & $50-100$ & 3 \\
\hline 5 & FLOMIN F200 & Frother & $40-50$ & 1 \\
\hline
\end{tabular}

to establish the bulk mineralogical composition of the ore by identifying the major crystalline phases. The bulk mineralogical composition obtained by XRD needed to be validated by elemental analysis because amorphous minerals are not detectable by XRD since it can only identify crystalline particles (Dish, 1994). Hence additional pulverized samples were analysed using X-ray fluorescence (XRF) to establish the elemental composition of the ore.

\section{Batch flotation tests}

Batch flotation tests were carried out on samples milled to $80 \%$ $-75 \mu \mathrm{m}$ at a slurry density of approximately $30 \% \mathrm{w} / \mathrm{w}$ solids. Synthetic plant water was prepared using distilled water modified by addition of ionic salts to achieve the ionic strength typical of process water at concentrator plants (Wiese, Harris, and Bradshaw, 2005). The tests were carried out using a $2.5 \mathrm{~L}$ modified Leeds cell and a Denver machine operated at an impeller speed of $1200 \mathrm{r} / \mathrm{min}$. The three co-collector schemes and conditions shown in Table II were tested to select the best reagent scheme for flotation recovery of PGMs into the rougher concentrates.

Concentrates were collected manually by scraping off the froth every 15 seconds into collection trays for 20 minutes of cumulative flotation time. All flotation products were filtered, dried, weighed, and analysed for PGMs by fire assay with an ICPOES finish.

\section{Leaching tests}

PGM dissolution test work was carried out on representative ROM samples milled to $80 \%-75 \mu \mathrm{m}$ using aqua regia, $\mathrm{HCL}, \mathrm{HNO}_{3}$, and $\mathrm{H}_{2} \mathrm{SO}_{4}$ to establish the extent of hydrometallurgical PGM extractionre. All leaching tests were conducted in a $500 \mathrm{~mL}$ round-bottom flask constantly agitated at $500 \mathrm{r} / \mathrm{min}$ by a magnetic stirrer. A reflux condenser was used to maintain a constant pulp density by minimizing liquid evaporative losses.

Base metal leaching with sulphuric acid was conducted on flotation rougher concentrates to establish the efficiency of upgrading of the low-grade PGM concentrates.

\section{Results and discussion}

\section{Characterization}

This section presents the characterization findings and the composition of the ore.

\section{Elemental analysis}

Table III shows the elemental composition of the oxidized ROM ore determined by XRF.

\section{Bulk mineralogy}

The oxidized PGM ore feed sample was dominated by silicate gangue minerals such as chabazite $(21.82 \%)$ and quartz (45.10\%). Magnetite was identified as the major iron oxide, accounting for $33.07 \%$ of the ore. The ore also contained trace quantities of enstatite and anorthite. Chromite and magnesiochromite were also identified as trace minerals. The mineralogical characterization test work confirmed that the Mimosa ore sample studied was a non-sulphide ore.

\section{Table III}

Elemental analysis (by XRF) of the oxidized PGM ore

\begin{tabular}{|c|c|c|}
\hline Item no. & Element & XRF analysis (wt $\%)$ \\
\hline 1 & $\mathrm{Na}$ & 0.54 \\
\hline 2 & $\mathrm{Mg}$ & 18.10 \\
\hline 3 & Al & 5.25 \\
\hline 4 & $\mathrm{Si}$ & 32.00 \\
\hline 5 & P & 0.03 \\
\hline 6 & $S$ & 0.64 \\
\hline 7 & $\mathrm{Cl}$ & 0.04 \\
\hline 8 & K & 0.41 \\
\hline 9 & $\mathrm{Ca}$ & 7.12 \\
\hline 10 & $\mathrm{Ti}$ & 0.50 \\
\hline 11 & V & 0.11 \\
\hline 12 & $\mathrm{Cr}$ & 7.97 \\
\hline 13 & $\mathrm{Mn}$ & 0.42 \\
\hline 14 & $\mathrm{Fe}$ & 25.90 \\
\hline 15 & Co & 0.05 \\
\hline 16 & $\mathrm{Ni}$ & 0.58 \\
\hline 17 & $\mathrm{Cu}$ & 0.31 \\
\hline 18 & $\mathrm{Zn}$ & 0.05 \\
\hline 19 & Sr & 0.02 \\
\hline \multicolumn{2}{|c|}{ Total } & 100 \\
\hline
\end{tabular}




\section{PGM extraction from oxidized ores using flotation and leaching}

\begin{tabular}{|c|c|c|c|c|c|}
\hline \multicolumn{6}{|c|}{$\begin{array}{l}\text { Table IV } \\
\text { PGM head assay results for the Mimosa oxidized ore } \\
\text { sample }\end{array}$} \\
\hline \multirow{2}{*}{ Item } & \multirow{2}{*}{ Description } & \multicolumn{4}{|c|}{ Assay (ppm) } \\
\hline & & Pt & $\mathbf{P d}$ & $\mathrm{Au}$ & $3 E$ \\
\hline 1 & Sample 1 & 1.45 & 0.85 & 0.09 & 2,39 \\
\hline 2 & Sample 2 & 1.38 & 0.84 & 0.09 & 2,31 \\
\hline \multicolumn{2}{|c|}{ Average } & 1,42 & 0.85 & 0.09 & 2.35 \\
\hline
\end{tabular}

\section{Head assay}

The concentrations of PGMs in the oxidized ROM ore as determined by fire assay with ICP-OES finish are presented in Table IV.

The average PGM assay value obtained for the Mimosa oxidized PGM ore was $2.35 \mathrm{~g} / \mathrm{t} 3 \mathrm{E}$. The low PGM head grade and elevated concentrations of silicate and iron-based gangue minerals compared to pristine ores help to explain the challenges encountered during beneficiation by conventional processes (Xiao and Laplante, 2004). Hence, non-conventional flotation reagent schemes were investigated in an attempt to improve the PGM rougher flotation recoveries from this ore sample.

\section{Flotation test work}

Table $\mathrm{V}$ presents the best results obtained from the reagent dosage permutations tested. In all cases, each reagent was tested at two levels (high and low) resulting in eight different reagent conditions for each reagent scheme. The scouting tests established that scheme 3 (hydroxamate-AM810 co-collector) achieved the best PGM flotation recoveries compared to the sulphide co-collectors, as shown in Table V. The AM810 cocollector was therefore adopted for further test work.

The effect of increasing AM810 co-collector dosage on PGM recovery is shown in Figure 1. These preliminary flotation tests suggest that PGM flotation recovery improves with increasing hydroxamate dosages at low SIBX dosages.

Increasing the hydroxamate AM810 dosage at constant SIBX caused a marginal increase in the Pt recovery and a significant increase in the Pd recovery. This is consistent with results of an earlier study (Shackleton, Malysiak, and O'Connor, 2007) which indicated that $\mathrm{Pd}$ mineral species are more prone to oxidation than Pt species. Hence, the hydroxamate oxide co-collector was more effective in improving the rougher flotation recoveries of $\mathrm{Pd}$ mineral species compared to $\mathrm{Pt}$, which is relatively resistant to oxidation because of its greater nobility.

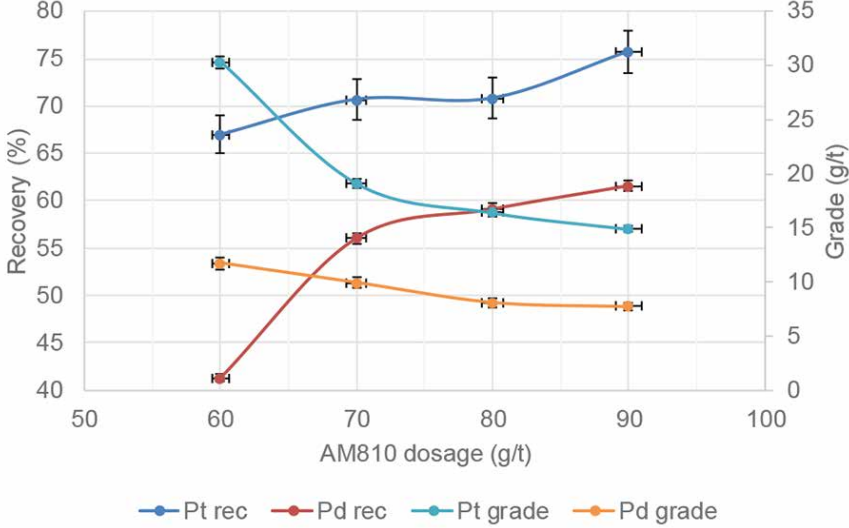

Figure 1-PGM flotation recoveries and grades obtained at different AM810 dosages at constant SIBX dosage

The improvement in recovery resulted in a significant decrease in grade, especially for Pt, which suggests poor selectivity of the AM810 co-collector for PGM-bearing minerals over the range investigated. The frothing properties of alkyl hydroxamates, which were investigated by previous workers (Yoon et al., 1992; Becker. Wiese, and Ramonotsi, 2014), most probably contributed to poor selectivity at high alkyl hydroxamate dosages. This suggests that an increase in hydroxamate dosage must be accompanied by a compensating decrease in frother dosage and changes to other reagents to avoid excessive frothiness, which could result in gangue entrainment.

Having established that increasing only the AM810 dosage achieved limited improvement in PGM recovery, the SIBX dosages were simultaneously altered to influence the interactions between SIBX and AM810. The step sizes of reagent dosages for this stage of reagent optimization were determined using the steepest ascent method (Myers, Montgomery, and Anderson-Cook, 2009). Figure 2 and Figure 3 show that PGM recovery and grade generally improved with decreasing SIBX dosage and increasing hydroxamate dosages for the range investigated.

This observation suggested that the oxide co-collector AM810 is more selective when the interactions of the primary collector are minimized by lowering the SIBX dosages. Although earlier work (Lee et al., 2009) showed that hydroxamates do not reduce the efficiency of primary collectors, the results of this study have shown that high dosages of primary sulphide collector (SIBX) adversely affect the efficiency of AM810 hydroxamate co-collector. Therefore, the interactions between primary sulphide collectors and the hydroxamate are influential in reagent

Table $V$

Preliminary reagent scouting test work results

\begin{tabular}{|l|l|c|c|c|c|c|c|c|}
\hline \multirow{2}{*}{ Test conditions } & \multirow{2}{*}{ Collector suite } & \multicolumn{3}{|c|}{ Reagent dosage (g/t) } & \multicolumn{3}{c|}{ Recovery (\%) } \\
\cline { 3 - 9 } & SIBX & Co-collector & $\begin{array}{c}\text { Depressant } \\
\text { (M98B) }\end{array}$ & Pt & Pd & Au & 3E \\
\hline Reagent scheme 1 & SIBX \& DTP & 100 & 50 & 50 & 66.1 & 40.1 & 24.2 & 55.1 \\
\hline Reagent scheme 2 & SIBX \& xanthogen formate & 150 & 50 & 100 & 60.9 & 37.7 & 40.5 & 51.8 \\
\hline Reagent scheme 3 & SIBX \& hydroxamate & 150 & 50 & 50 & 74.0 & 48.4 & 29.9 & 63.1 \\
\hline
\end{tabular}




\section{PGM extraction from oxidized ores using flotation and leaching}

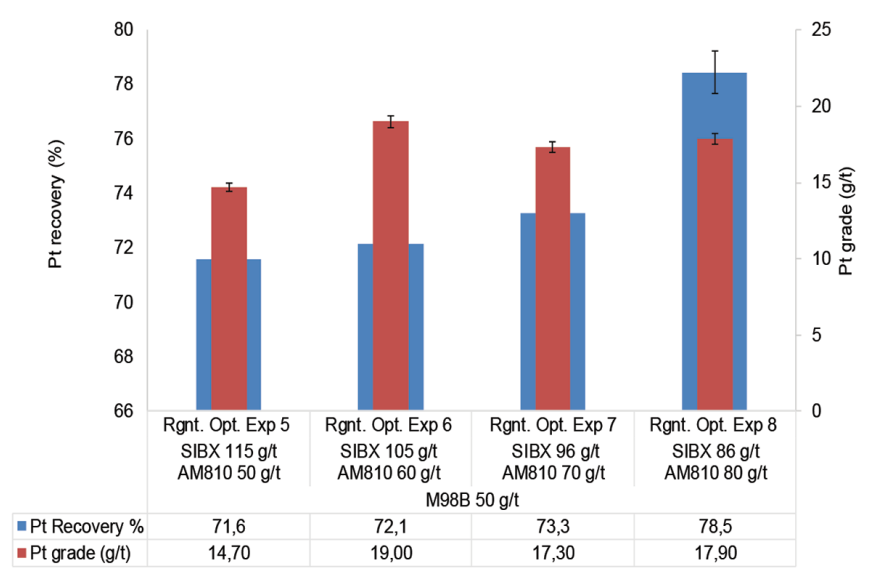

Figure 2-Steepest ascent method for flotation reagent optimization platinum recovery and grade results

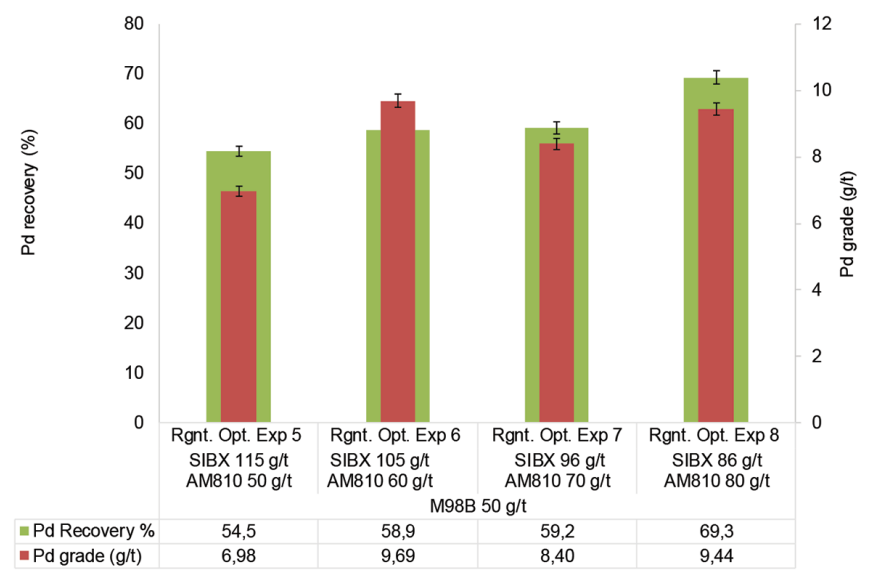

Figure 3-Steepest ascent method for flotation reagent optimization - palladium recovery and grade results

optimization. Application of the steepest ascent method resulted in an optimum rougher recovery of $\mathrm{Pt}$ and $\mathrm{Pd}$ of $78.5 \%$ and $69.3 \%$ respectively at modest grades of 17.90 and $9.44 \mathrm{~g} / \mathrm{t}$.

\section{Dissolution test work}

\section{PGM dissolution test work}

The PGM dissolution test work was carried out on representative samples milled to $80 \%-75 \mu \mathrm{m}$ using four different acids to establish the best lixiviant system for extraction of PGMs from the ROM oxidized PGM ore. The acids investigated were hydrochloric acid $(\mathrm{HCl})$, nitric acid $\left(\mathrm{HNO}_{3}\right)$, sulphuric acid $\left(\mathrm{H}_{2} \mathrm{SO}_{4}\right)$, and aqua regia. The acid dissolution tests established that aqua regia was the best lixiviant for hydrometallurgical recovery of PGMs, as shown in Figure 4.

The aqua regia solution achieved superior extractions compared to other lixiviants tested because PGMs form stable chloro-complexes under the high oxidation conditions provided by the reactions of $\mathrm{HCl}$ and $\mathrm{HNO}_{3}$ (Lide, 1995). Therefore, further PGM dissolution tests using aqua regia were conducted to establish the effect of pulp density, leaching temperature, and cumulative leaching time on PGM recovery. The results are shown in Figure 5-7.

Figure 5 shows that pulp density had a significant effect on the leaching extractions of Pt and Pd. High extractions were achieved at low solids/liquid ratio, probably because of the availability of more lixiviant interacting with solids (Hosseini et al., 2017). Increasing the solid/liquid ratio possibly caused premature consumption of the lixiviant by gangue minerals before leaching the targeted PGMs, since the low-grade ROM ore was processed without prior upgrading at this stage of the test work. Therefore a solid/liquid ratio of $2 \mathrm{~g}$ per $100 \mathrm{ml}$ was used in subsequent dissolution tests to evaluate the effects of temperature and leaching time on PGM leaching recovery. The overall PGM dissolution generally increased with leaching temperature and time for the conditions studied, as shown in Figure 6 and 7 . These observations are consistent with the literature (Baghalha, Khosravian, and Mortaheb, 2009), because a higher temperature improved the reactions kinetics while prolonged leaching time ensures that the leaching reactions reach equilibrium.

The results of two processing routes investigated in this study suggest that the most promising preconcentration route for these resources seems to be flotation using oxide co-collectors such as hydroxamates. Hydrometallurgical processing of ROM ore was not efficient, like other preconcentration alternatives such as gravity methods, which were proved to be inefficient by previous researchers (Oberthür et al., 2013).

The low-grade of the flotation concentrate obtained with hydroxamate co-collector suggests the need to investigate concentrate upgrading using cleaning stages. The cleaning stages would improve the concentrate grades at the cost of overall PGM flotation recoveries but will probably reduce the operating costs of subsequent hydrometallurgical processes because most of the reagent-consuming gangue will be rejected.

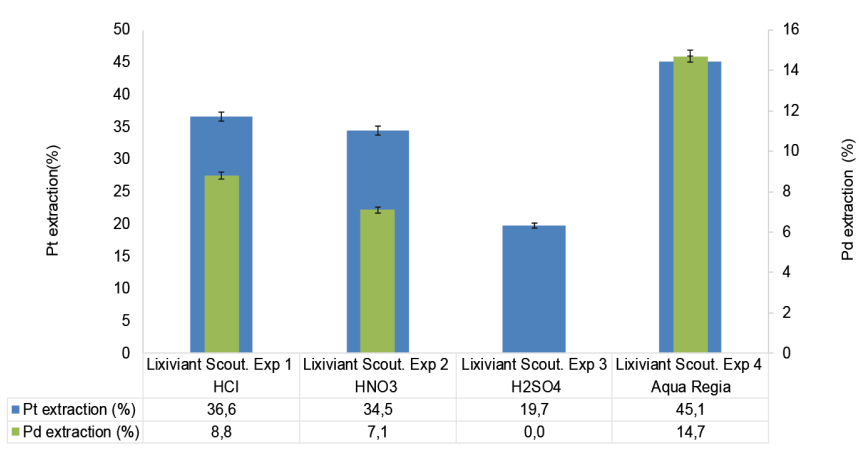

Figure 4-PGM lixiviant scouting test work results

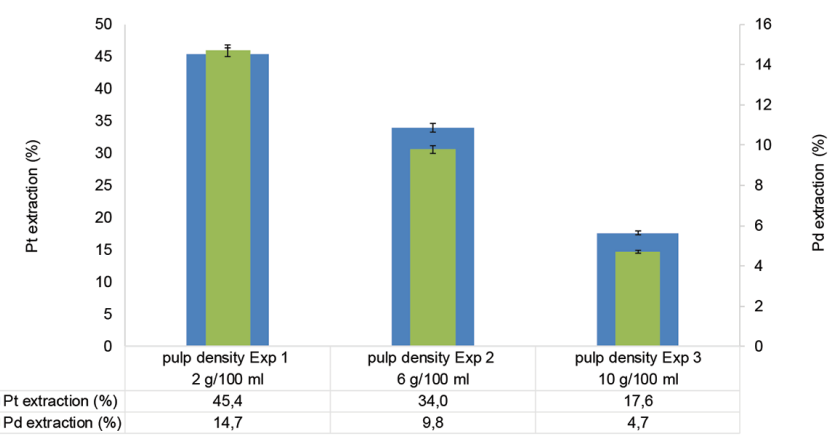

Figure 5-Effect of solid/liquid ratio on PGM leaching extraction 


\section{PGM extraction from oxidized ores using flotation and leaching}

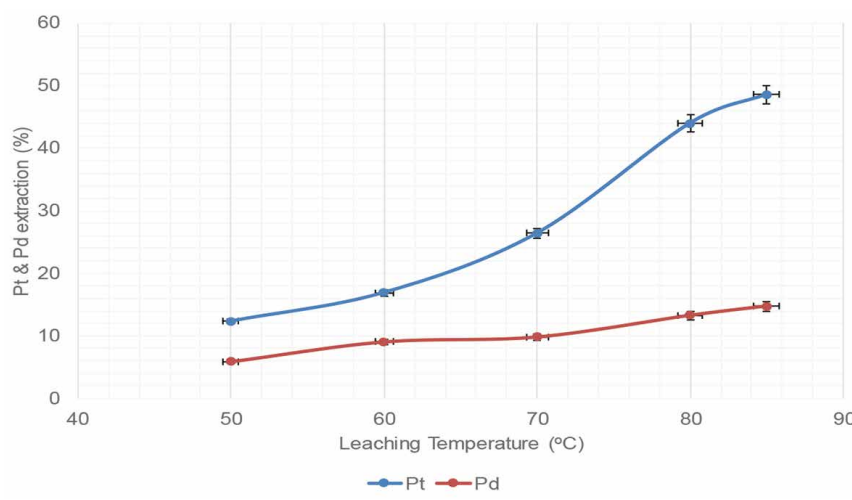

Figure 6-Effect of leaching temperature on PGM extraction

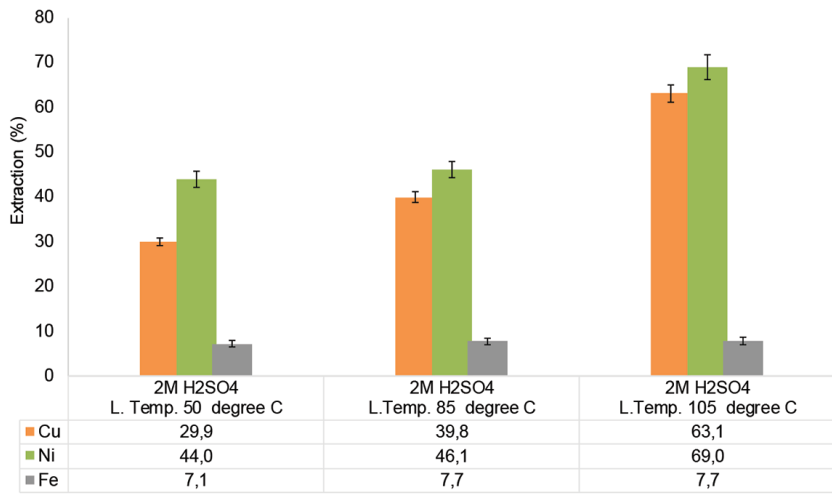

Figure 9-Effect of temperature on base metal leaching at $2 \mathrm{M} \mathrm{H}_{2} \mathrm{SO}_{4}$ concentration

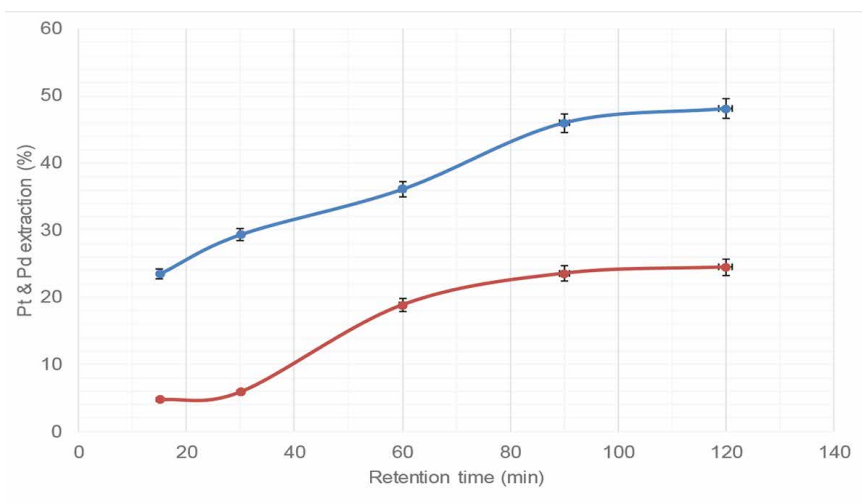

Figure 7-Effect of leaching time on PGM extraction

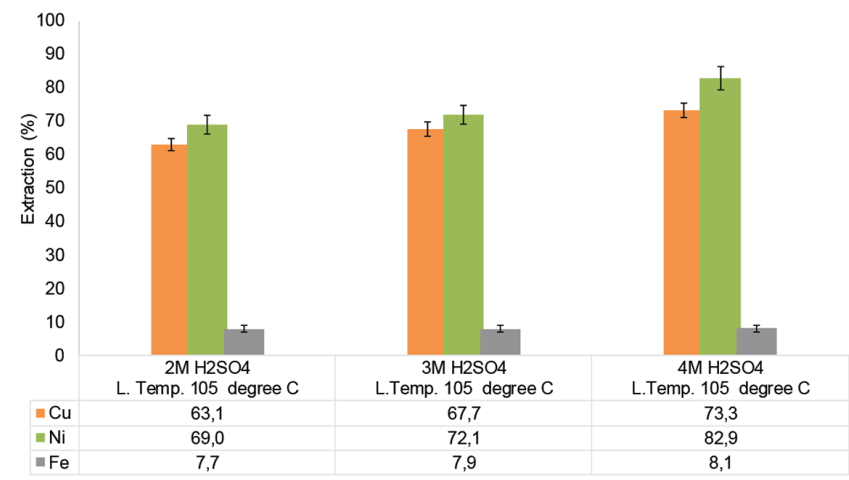

Figure 8-Effect of acid concentration on base metal leaching

\section{Base metal dissolution test work}

The PGM lixiviants investigated in recent studies, such as sodium cyanide, thiocyanate, and aqua regia, are nonselective and hence pre-leaching of base metals is necessary to minimize reagent consumption (Mpinga et al., 2015). The results of hydrometallurgical upgrading of low-grade PGM concentrates by removing base metals using atmospheric sulphuric acid leaching are presented in Figure 8-Figure 11.

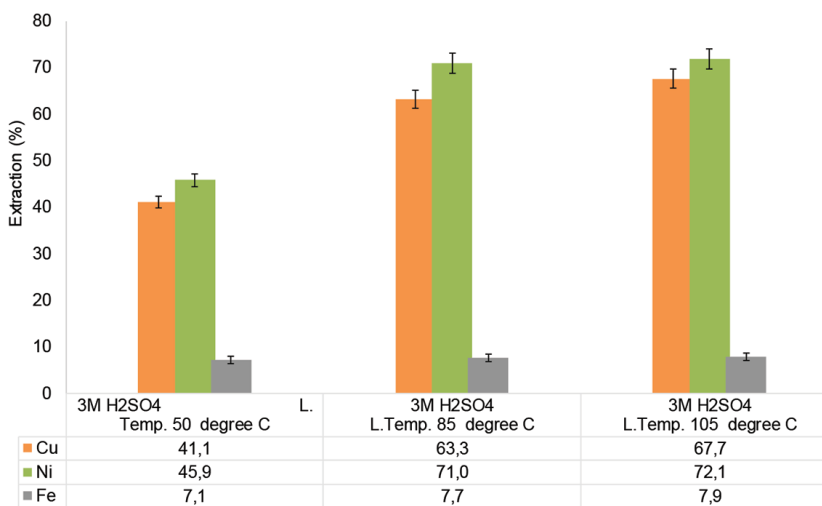

Figure 10-Effect of temperature on base metal leaching at $3 \mathrm{M} \mathrm{H}_{2} \mathrm{SO}_{4}$ concentration

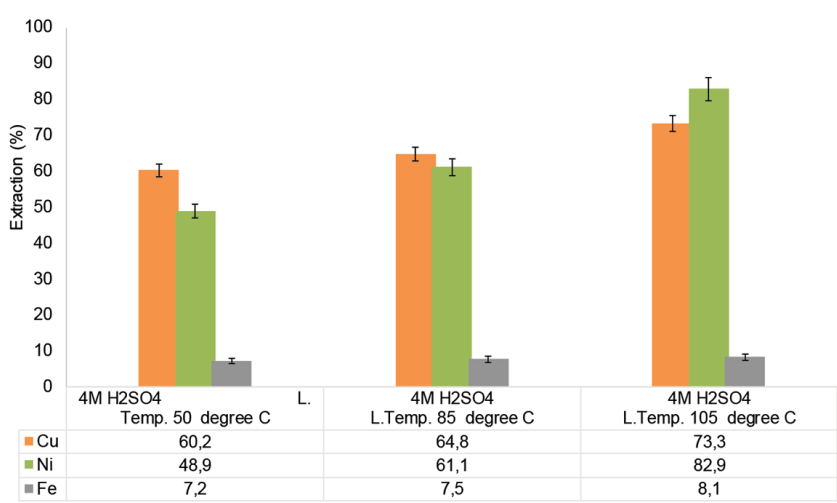

Figure 11-Effect of temperature on base metal leaching at $4 \mathrm{M} \mathrm{H}_{2} \mathrm{SO}_{4}$ concentration

The highest base metal extractions by atmospheric pressure $\mathrm{H}_{2} \mathrm{SO}_{4}$ leaching, of $82.9 \%, 73.3 \%$, and $8.1 \%$ for $\mathrm{Ni}$, $\mathrm{Cu}$, and Fe respectively, were obtained at $4 \mathrm{M} \mathrm{H}_{2} \mathrm{SO}_{4}$ concentration and $105^{\circ} \mathrm{C}$. The Fe leaching extraction was characteristically low, which suggests that more intensive conditions such as hightemperature and high-pressure processes may need to be adopted for efficient extraction of Fe prior to subsequent PGM leaching (Mpinga et al., 2015).

The Journal of the Southern African Institute of Mining and Metallurgy 


\section{PGM extraction from oxidized ores using flotation and leaching}

\begin{tabular}{|c|c|c|c|c|c|c|c|}
\hline \multicolumn{8}{|c|}{$\begin{array}{l}\text { Table VI } \\
\text { Bill of materials for flotation and leaching routes }\end{array}$} \\
\hline \multicolumn{8}{|c|}{ Total revenue/ton ore processed } \\
\hline \multirow[b]{2}{*}{ Description } & \multirow[b]{2}{*}{$\begin{array}{c}\text { Head } \\
\text { assays }\end{array}$} & \multicolumn{3}{|c|}{ Flotation route } & \multicolumn{3}{|c|}{ Leaching route } \\
\hline & & Recovery (\%) & $\begin{array}{l}\text { Mass }(g) \\
\text { produced/ } \\
\text { ton ore }\end{array}$ & Revenue & Recovery (\%) & $\begin{array}{l}\text { Mass }(\mathbf{g}) \\
\text { produced } / \\
\text { ton ore }\end{array}$ & Revenue \\
\hline Pt & 1.42 & 78.7 & 1.12 & ZAR 438.00 & 48.6 & 0.69 & ZAR 270.33 \\
\hline Pd & 0.85 & 69.6 & 0.59 & ZAR 261.50 & 14.7 & 0.12 & ZAR 55.24 \\
\hline \multicolumn{4}{|c|}{ Totals } & ZAR 699.50 & & & ZAR 325.56 \\
\hline \multicolumn{4}{|c|}{ Discounted total revenue } & ZAR 349.75 & & & ZAR 162.78 \\
\hline
\end{tabular}

\begin{tabular}{|c|c|c|c|c|c|c|c|c|}
\hline \multicolumn{9}{|c|}{ Reagent costs } \\
\hline \multirow[b]{2}{*}{ Material ID } & \multirow[b]{2}{*}{$\begin{array}{l}\text { Unit cost } \\
\text { (ZAR/ton }\end{array}$} & \multicolumn{2}{|c|}{ Flotation route } & \multicolumn{5}{|c|}{ Leaching route } \\
\hline & & dosage $(g / t)$ & $\begin{array}{l}\text { Operating } \\
\text { cost (ZAR/ } \\
\text { ton ore }\end{array}$ & Solid/liquid ratio & $\begin{array}{l}\text { Startup mass } \\
(\mathrm{kg})\end{array}$ & $\begin{array}{l}\text { Startup Cost } \\
\text { ZAR }\end{array}$ & Topup mass (kg) & $\begin{array}{l}\text { Operating cost } \\
\text { (ZAR/ ton ore }\end{array}$ \\
\hline Cost of ore/ ton & ZAR 50.00 & - & ZAR 50.00 & - & & & & ZAR 50.00 \\
\hline SIBX collector & ZAR 21819.61 & 150 & ZAR 3.27 & & & & & \\
\hline $\begin{array}{l}\text { AM810 hydroxamate } \\
\text { co-collector }\end{array}$ & $\begin{array}{l}\text { ZAR } 117 \\
6548.00\end{array}$ & 80 & ZAR 9.41 & & & & & \\
\hline Copper sulphate & ZAR 22804.50 & 50 & ZAR 1.14 & & & & & \\
\hline F200 frother & ZAR 30000.00 & 50 & ZAR 1.50 & & & & & \\
\hline $\mathrm{HCl}$ & ZAR 2181.30 & 0 & & $2 \mathrm{~g} / 100 \mathrm{ml}$ & 44625.00 & 97340.51 & 44.625 & ZAR 97.34 \\
\hline $\mathrm{HNO}_{3}$ & ZAR 6107.64 & 0 & & $2 \mathrm{~g} / 100 \mathrm{ml}$ & 17500.00 & 106883.70 & 17.50 & ZAR 106.88 \\
\hline \multicolumn{3}{|c|}{ Total costs } & ZAR 65.33 & & & 204224.21 & & ZAR 254.22 \\
\hline \multicolumn{3}{|c|}{ Gross profit/loss } & ZAR 284.42 & & & & & -ZAR 91.44 \\
\hline \multicolumn{3}{|c|}{ Percentage gross profit/loss } & $81 \%$ & & & & & $-56 \%$ \\
\hline
\end{tabular}

\section{Economic evaluation of flotation and leaching routes}

Table VI shows a preliminary economic evaluation of the flotation and leaching processes.

The following assumptions were made for the economic evaluation calculations.

$>$ The cost of recovering the oxidized PGM ore from stockpiles was assumed to be R50 per ton, since no additional mining would be required

> The total revenues of PGMs in the flotation concentrate and leach liquor were discounted by $50 \%$, considering that further processing to produce pure metal would still be necessary in each case.

The reagent costs were based on quotations from bulk chemical suppliers in the mining industry. The flotation route was shown to be profitable, with revenue exceeding reagent costs by $81 \%$ while the leaching route showed a deficit of $-56 \%$. This suggests that leaching of ROM ore would result in excessive lixiviant consumption at the pulp density tested, and hence different operating conditions for the hydrometallurgical route must be developed for the leaching process to be feasible. Although the profitability of the flotation route will be reduced when other operating costs such as utilities and labour are considered, this preliminary economic evaluation indicated that more research effort should be directed towards optimizing flotation as the first preconcentration step, as opposed to purely hydrometallurgical processing.

\section{Conclusion}

Flotation and hydrometallurgical processing routes for improving PGM recovery from a non-sulphide or oxidic PGM ore were investigated. The results indicated that alkyl hydroxamate cocollectors were most effective for flotation recovery of PGMs from oxidized ore, with $78.5 \%$ Pt recovery using AM810. The superior PGM recoveries achieved by the AM810 co-collector were attributed to the ability of hydroxamates to form stable complexes by chelation with metals such as iron and copper, which are present in PGM-bearing minerals. The superior improvement in Pd flotation recoveries compared to Pt suggested that Pd mineral species were more oxidized and hence amenable to oxide cocollector than Pt species. The low flotation concentrate grades were attributed to the frothing properties of hydroxamates, which suggests that more tests need to be conducted to establish selective conditions. Additionally, cleaner flotation tests should be completed on rougher flotation concentrates produced using hydroxamates to determine the potential extent of upgrading and hence evaluate the feasibility of this processing route. 


\section{PGM extraction from oxidized ores using flotation and leaching}

PGM extraction from ROM ore by aqua regia leaching was strongly dependent on dissolution temperature and pulp density, with high temperatures $\left(85^{\circ} \mathrm{C}\right)$ and low solid to liquid ratios $(2$ $\mathrm{g}$ per $100 \mathrm{ml}$ ) obtaining the best PGM recoveries of $48 \%$ for Pt and $24.5 \%$ for Pd. However, the hydrometallurgical processing of ROM ore using nonselective solvents like aqua regia would not be recommended because of the high lixiviant consumptions. The use of flotation co-collectors such as hydroxamates as the first preconcentration step would be a more practical solution, and smelting or leaching can be carried out as the subsequent extraction stage. The low-grade flotation concentrate may be upgraded hydrometallurgically using sulphuric acid pressure leaching, because the atmospheric conditions used in this study achieved limited base metal extractions $(73.3 \% \mathrm{Cu}, 82.9 \% \mathrm{Ni}$, and $8.1 \% \mathrm{Fe})$.

\section{Acknowledgements}

The authors wish to thank the National Research Foundation (NRF) for financial support during this project. Acknowledgements also go to Chemquest and Axis House for supplying the flotation reagents.

\section{References}

Assis, S., Montenegro, L., and Peres, A. 1996. Utilisation of hydroxamates in minerals froth flotation. Minerals Engineering, vol. 9, no. 1. pp. 103-114.

Baghalha, M., Khosravian, H.G., and Mortaheb, H. R. 2009. Kinetics of platinum extraction from spent reforming catalysts in aqua-regia solutions. Hydrometallurgy, vol. 95, no. 3. pp. 247-253.

Becker, M., Wiese, J., and RAmonotsi, M. (2014). Investigation into the mineralogy and flotation performance of oxidised PGM ore. Minerals Engineering, vol. 65. pp. 24-32.

BuckLey, A.N. and Woods, R. 1984. An X-ray photoelectron spectroscopic study of the oxidation of chalcopyrite. Australian Journal of Chemistry, vol. 36. pp. 2403-2413.

CASTRo, S., GoldFarB, J., and LaskowsKI, J. 1974. Sulphidizing reactions in the flotation of oxidized copper minerals, I. Chemical factors in the sulphidization of copper oxide. International Journal of Mineral Processing, vol. 1, no. 2. pp. 141-149.

CRAmER, L.A. 2001. The extractive metallurgy of South Africa's platinum ores. Journal of the Minerals, Metals and Materials Society, vol. 10. pp. 14-18.

Dish, D. 1994. Quantitative X-ray diffraction analysis of soils. Quantitative Methods in Soil Mineralogy. pp. 267-295.

Elvy, S.B., Williams, P.A., and BuckLeY, A.N. 1995. XPS evidence for the incongruent surface oxidation of minerals in the Pd-Te-Bi system. Surface and Interface Analysis, vol. 95. pp. 525-534.

Evans, D.M. 2002. Potential for bulk mining of oxidized platinum-group element deposits. Applied Earth Science, vol. 111, no. 1. pp. 81-86.

Hosseini, S.A., Raygan, S., Rezaei, A., and Jafari, A. 2017. Leaching of nickel from a secondary source by sulfuric acid. Journal of Environmental Chemical Engineering, vol. 5, no. 4. pp. 3922-3929.

Kongolo, K., KipoKa, M., MinAnga, K., and Mpoyo, M. 2003. Improving the efficiency of oxide copper-cobalt ores flotation by combination of sulphidisers. Minerals Engineering, vol. 16. pp. 1023-1026.

Lee, K., Archibald, D., McLean, J., and Reuter, M. 2009. Flotation of mixed copper oxide and sulphide minerals with xanthate and hydroxamate collectors. Minerals Engineering, vol. 22, no. 4. pp. 395-401.

Legrand, D., Bancroft, G., and Nesbitt, H. 2005. Oxidation/alteration of pentlandite and pyrrhotite surfaces at $\mathrm{pH}$ 9.3: part 1. Assignment of XPS spectra and chemical trends. American Mineralogist, vol. 90, no. 7. pp. 1042-1054.
LIDE, D.R. (1995. CRC Handbook of Chemistry and Physics. CRC Press, London. pp. 1994-1995.

Mielczarski, J.A., CASEs, J.M., Alnot, M., and Ehrhardt, J.J. 1996. XPS characterization of chalcopyrite, tetrahedrite and tennantite surface products after different conditioning. 1. Aqueous solution at pH 10. Langmuir, vol. 10. pp. 2519-2530.

Mpinga, C.N., EKsteen, J.J., Aldrich, C., and Dyer, L. 2015. Direct leach approaches to platinum group metal (PGM) ores and concentrates: A review. Minerals Engineering, vol. 78. pp. 93-113.

MusonDA, K.J. 2015. Ammonia leaching as a pre-treatment for the processing of oxidised PGM ores. MSc thesis, University of Cape Town.

Mwase, J.M., Petersen, J., and Eksteen, J.J. 2012. A conceptual flowsheet for heap leaching of platinum group metals (PGMs) from a low-grade concentrate. Hydrometallurgy, vol. 111. pp. 129-135.

Mwase, J. and Petersen, J. 2017. Characterizing the leaching of sperrylite $\left(\mathrm{PtAs}_{2}\right)$ in cyanide-based solutions. Hydrometallurgy, vol. 172. pp. 1-10.

Myers, R.H., Montgomery, D.C., and Anderson-Cook, C.M. 2009. Response Surface Methodology - Process and Product Optimisation Using Designed Experiments. Wiley, Hoboken, NJ.

Newell, A. and Bradshaw, D. 2007. The development of a sulfidisation technique to restore the flotation of oxidised pentlandite. Mineralogical Engineering, vol. 20, no. 10. pp. 1039-1046.

Oberthür, T., Melcher, F., BuchHolz, P., and Locmelis, M. 2013. The oxidized ores of the Main Sulphide Zone, Great Dyke, Zimbabwe: turning resources into minable reserves - mineralogy is the key. Journal of the Southern African Institute of Mining and Metallurgy, vol. 113, no. 3. http://www.scielo.org.za/ scielo.php?script=sci_arttext\&pid=S2225-62532013000300009

ORWE, D., Grano, S., and LAUDER, D. 1998. Increasing fine copper recovery at the Ok Tedi concentrator, Papua New Guinea. Minerals Engineering, vol. 11, no. 2. pp. 171-187.

RAmonotsi, M. 2011. Characterisation of the effect of alteration on the PPM platinum ore and evaluation of selected strategies to improve metallurgical performance. MSc thesis, University of Cape Town.

Sefako, R., Sekgarametso, K., and Sibanda, V. 2017. Potential processing routes for recovery of platinum groug metals from Southern African oxidised PGM ores: A review. Journal of Sustainable Metallurgy, vol. 3, no. 4. pp. 797-807.

SHAcкLEтon, N.J. 2007. Surface characterisation and flotation behaviour of the platinum and palladium arsenide, telluride and sulphide mineral species. $\mathrm{PhD}$ thesis, University of Cape Town.

Shackleton, N.J, Malysiak, V., and O'Connor C.T. 2007. Surface characteristics and flotation behaviour of platinum and palladium tellurides. Minerals Engineering, vol. 20, no. 13. pp. 1232-1245.

Shaik, K. and Petersen, J. 2017. An investigation of the leaching of Pt and Pd from cooperite, sperrylite column bioleached concentrates in thiocyanate-cyanide systems. Hydrometallurgy, August 2017. pp. 210-217.

VAUGHAN, D.J., BECKER, U., and Wright, K. 1997. Sulphide mineral surfaces: theory and experiment. International Journal of Mineral Processing, vol. 51. pp. 1-14.

Wiese, J., Harris, P., and Bradshaw, D. 2005. The influence of the reagent suite on the flotation of ores from the Merensky reef. Minerals Engineering, vol. 18, no. 2. pp. 189-198.

XIAo, Z. and LAPLANTE, A.R. 2004. Characterizing and recovering the platium group minerals - a review. Minerals Engineering, vol. 17, no. 9-10. pp. 961-79.

Yoon, R.H., NAgaraj, D.R., Wang, S.S., and Hildebrand, T.M. 1992. Beneficiation of kaolin clay by froth flotation using hydroxamate collectors. Minerals Engineering, vol. 5, no. 3. pp. 457-467. 